\title{
Effect of endodontic irrigating solutions on the adhesive bond strength to dentin
}

\author{
Efeito de soluções irrigadoras endodônticas na \\ resistência adesiva à dentina
}

\begin{abstract}
Purpose: To evaluate the bond strength of a total-etching adhesive system to dentin irrigated with $1 \%$ sodium hypochlorite $(\mathrm{NaOCl})$ and ethylenediaminetetraacetic acid $17 \%$ (EDTA).

Methods: Thirty human molars were sectioned $3 \mathrm{~mm}$ below the oclusal surface and were randomly divided into 3 groups ( $n=10$ ): $\mathrm{G} 1$, no treatment (control); G2, $1 \% \mathrm{NaOCl}^{\circ} \mathrm{G} 3$, $\mathrm{NaOCl}$ followed by EDTA. The specimens received the total-etching adhesive system, restored with microhybrid composite resin, sectioned and trimmed to create 4 hourglass-shaped slabs of each tooth. The slabs were tested in microtensile bond strength in a universal testing machine (Emic DL 2000) at a crosshead speed of $0.5 \mathrm{~mm} / \mathrm{min}$ until fracture. The results were analyzed statistically by ANOVA and Newman-Keuls test. G2 samples were not submitted to the test because they fractured just before testing, and its values were considered zero to the statistical analysis.
\end{abstract}

Results: The means and standard deviations (MPa) were: G1, 8.41 ( \pm 3.51$) ; \mathrm{G} 2,0.0$ ( \pm 0.00$)$; G3, $8.47( \pm 3.53)$.

Conclusion: It was concluded that the application of the $\mathrm{NaOCl}$ irrigating solution significantly decreased the bond strength values. The use of $\mathrm{NaOCl}$ followed by EDTA resulted in bond strength values not statistically different from control group.

Key words: Adhesives; dentin; root canal irrigants

\section{Resumo}

Objetivo: Avaliar a resistência de união de um sistema adesivo condicione-e-lave à dentina irrigada com hipoclorito de sódio $1 \%(\mathrm{NaOCl})$ e ácido etilenodiaminotetracético $17 \%$ (EDTA).

Metodologia: Trinta molares humanos foram seccionados $3 \mathrm{~mm}$ abaixo da superficie oclusal e aleatoriamente divididos em 3 grupos ( $n=10): \mathrm{G} 1$ (controle), nenhum tratamento; $\mathrm{G} 2, \mathrm{NaOCl}$; $\mathrm{G} 3, \mathrm{NaOCl}$ seguido por EDTA. Os especimes foram hibridizados com um sistema adesivo condicione-e-lave, foram restaurados com resino composta microhibrida e seccionados de forma a originar 4 amplulhetas de cada dente. As fatias foram submetidas ao teste de resistência de união à microtraçnao em máquina universal de ensaios (EMIC DL 2000) à uma velocidade de $0,5 \mathrm{~mm} / \mathrm{min}$ até o momento da fratura. Os resultados foram analisados estatisticamente por ANOVA seguido por Newman-Keuls. As amostras do G2 não foram submetidas aos testes de resistência de união pois fraturaram antes dos testes, e seus valores foram considerados zero para análise estatística.

Resultados: A média e desvios-padrão foram (MPa): $G 1$ - 8,41 ( $\pm 3,51)$; $G 2$ - 0,0 ( $\pm 0,00)$; e G3 - 8,47 ( $\pm 3,53)$.

Conclusão: Pode-se concluir que a irrigação com $\mathrm{NaOCl}$ diminui significativamente os valores de resistência de união. $\mathrm{O}$ uso de $\mathrm{NaOCl}$ seguido por EDTA resultaram em valores de resistência de união sem diferença estatística com o grupo controle.

Palavras-chave: Adesivos; dentina; irrigantes endodônticos

\author{
Doglas Cecchin a \\ Ana Paula Farina ${ }^{a}$ \\ João Vicente Baroni Barbizam b \\ Maria Paula Gandolfi Paranhos ${ }^{\circ}$ \\ Bruno Carlini-Júnior a
}

a Department of Restorative Dentistry, School of Dentistry, University of Passo Fundo, Passo Fundo, RS, Brazil

b Department of Restorative Dentistry, School of Dentistry, University of Seatle, Seatle, Washington, USA

cDepartment of Restorative Dentistry, School of Dentistry, University of California, Los Angeles, California, USA

\author{
Correspondence: \\ Doglas Cecchin \\ Universidade de Passo Fundo, Campus I \\ Faculdade de Odontologia \\ BR 285, Km 171 - Bairro São José \\ Caixa Postal 611 \\ Passo Fundo, RS - Brazil \\ 99052-900 \\ E-mail:dgscecchin@yahoo.com.br
}

Received: September 7, 2011

Accepted: November 15, 2011

Conflict of Interests: The authors state that there are no financial and personal conflicts of interest that could have inappropriately influenced their work.

Copyright: (c) 2011 Cechin et al.; licensee EDIPUCRS. This is an Open Access article distributed under the terms of the Creative Commons AttributionNoncommercial-No Derivative Works 3.0 Unported License. 


\section{Introduction}

The dentine substrate is a hydrated biologic complex, with differential regional patterns that can be modified by physiological processes, age and disease (1). Bonding to dentin is a very complicated process, mainly due to its predominantly organic content, tubular structure, variety of substrate mineralization degrees and to the external fluids flux (2).

The actual adhesive systems contain substances that prepare the dentinal substrate for bonding. The acid etching removes the mineral portion and exposes the collagen fibers that must be kept moist. The forth generation adhesive systems bond to the demineralized and moist dentine tissue by means of acetone or alcohol-based primers that remove the water and maintain the collagen network, permitting resinous monomers penetration (3). This is a critical technique because of the subjectivity inherent to the ideal humidity and because of the possibility of maintaining exposed collagen fibers where the microleakage could be initiated (4). Therefore, one of the main reasons of the hybridization success is the achievement of dentine ideal conditions (2).

In the teeth where endodontic treatment is indicated, the combined use of endodontic irrigating solutions that clean, disinfect and shape the root canal system for posterior filling are necessary and essential for the therapy success $(5,6)$.

Among the endodontic irrigating solutions, indicated as auxiliaries for endodontic therapy, sodium hypochlorite is the most used all over the world due to its anti-bacterial and organic tissue dissolving properties, which are directly proportional to its concentration (7).

EDTA is also a solution commonly used in Endondotics. It acts on the dentin mineral content and promotes smear layer removal (8). The use of sodium hypochlorite followed by the final irrigation with EDTA, for smear layer removal, could enhance the contact between intra-canal irrigating solutions and filling materials with dentine walls (9).

However, the use of irrigating solutions during endodontic treatment could modify the dentine structure (10) and interfere on dentin/resin bonding (11-13). Therefore, the purpose of this study was to evaluate the bond strength of a totaletching adhesive system to dentin irrigated with $1 \%$ sodium hypochlorite $(\mathrm{NaOCl})$ and ethylenediaminetetraacetic acid $17 \%$ (EDTA). The null hypothesis that endodontic irrigants ( $\mathrm{NaOCl}$ and EDTA) do not affect the bond strength of the self-etching adhesive system to dentin.

\section{Material and Methods}

Thirty sound freshly-extracted human third molars were used in this study. Teeth were stored $0.5 \%$ chloramine solution at $4^{\circ} \mathrm{C}$ for $48 \mathrm{~h}$ for disinfection. Next, the teeth were cleaned with pumice/water slurry in Robinson brushes (Microdont; Socorro, SP, Brazil) and analyzed under x10 magnifying glass (Carl Zeiss; Jena, Germany) to exclude those with fracture lines or fissures. The teeth were stored in distilled water at $4^{\circ} \mathrm{C}$.
Each tooth was vertically embedded in a PVC cylinder (25 mm diameter and $20 \mathrm{~mm}$ high) using an auto-polymerizing acrylic resin (Jet Clássico Ind.; São Paulo, Brazil). The oclusal third $(3 \mathrm{~mm})$ of the molar crowns was removed by means of a slow speed saw (400 rpm) with a diamond disk (Arotec; São Paulo, Brazil) in a cutting machine (Struers Miniton; Paraná, Brazil) under constant water-cooling. The dentin was flattened with 600 and 1200-grit silicon carbide abrasive papers.

The specimens were randomly distributed into the following groups $(\mathrm{n}=10)$ : in group 1 (control), no irrigating solution was applied; in group $2,1 \% \mathrm{NaOCl}(5 \mathrm{~mL})$ was applied to the dentin surface every $5 \mathrm{~min}$ for $1 \mathrm{~h}$, simulating the time that $\mathrm{NaOCl}$ (based irrigants are usually left in the root canals during endodontic treatment under clinical conditions); in Group 3, 1\% $\mathrm{NaOCl}$ was applied as described for Group 2, followed by a 5-min final rinse with 17\% EDTA $(5 \mathrm{~mL})$, simulating the duration of the final flush with this chelating agent during endodontic treatment under clinical conditions. After dentin treatments, all specimens were washed with distilled water for $60 \mathrm{~s}$.

Two coats of the adhesive system (Single Bond, 3M/ ESPE; St. Paul, MN, USA) were applied, with a break of 20s after each adhesive coat, and photo-polymerized (Radii, SDI; São Paulo, SP, Brazil) for 20s after the second coat. After hybridization, 3 increments ( $2 \mathrm{~mm}$ each) of composite resin (Z250, 3M/ESPE; St. Paul, MN, USA) were applied over the dentine surface, using a spatula n. 1/2, completing $6 \mathrm{~mm}$ high. Each increment was photo-polymerized for 20 s. After bonding procedures specimens were stored in a sterilization oven in water for $24 \mathrm{~h}$, at $37^{\circ} \mathrm{C}$.

After storage in distilled water for $24 \mathrm{~h}$, the specimens were placed in a metallographic sectioning machine (Struers Miniton; Copenhagen, Denmark) and a water-cooled doublefaced diamond disk was used to cut sequential longitudinal 1.0 -mm-thick sections in a mesiodistal direction. Care was taken not to separate the slices. The specimens were then removed from the acrylic resin base through a transversal section, to obtain resin/dentin slabs measuring approximately 10-mm high, 5-mm wide and 1-mm thick. The slabs were trimmed on both sides of resin-dentin interface with a \#1093 FF bur (KG Sorensen; Barueri, SP, Brazil) at a high-speed handpiece (Kavo; Joinvile, SC, Brazil) to obtain a 1-mm thick central area and produce standard hourglass-shaped specimens.

The specimens were individually fixed in a metallic device with a cyanocrylate adhesive (Loctite Super Bonder; São Paulo, SP, Brazil) so that the resin/dentin interface remained without any contact for the microtensile test. The metallic device coupled to a universal testing machine (Emic DL 2000; São José of Pinhais, PR, Brazil) and the specimens were subjected to a microtensile strength at a crosshead speed of $0.5 \mathrm{~mm} / \mathrm{min}$ until fracture. At the moment of fracture, the resistance values were recorded in Newtons (N) by computer software. Before the test, the area was measured with a digital caliper (Vonder Digital Electronic Paquímetro; Curitiba, PR, Brazil) and the bond strength was 
calculated in MPa using the following equation: $R t=F / A$, where $R t$ is the $\mu$ TBS value, $F$ is the force applied and $A$ is the bond area between the dentin and restorative system. The data obtained were subjected to ANOVA and Newman Keuls tests $(\alpha=0.01)$.

For scanning electronic microscopy (SEM) analysis, specimens were immersed in $2.5 \%$ glutaraldehyde for 12 hours at $4^{\circ} \mathrm{C}$ for fixation, washed with $20 \mathrm{~mL}$ buffer solution of sodium cacodylate $0.2 \mathrm{M}$ with $\mathrm{pH} 7.4$ for 1 hour, and washed in distilled water three times for 1 minute. For dehydration, the specimens were sequentially immersed in ethyl alcohol (25\% for 20 minutes, $50 \%$ for 20 minutes, $75 \%$ for 20 minutes, and $95 \%$ for 20 minutes), and dried at $37^{\circ} \mathrm{C}$ for 48 hours with silica gel drying pearls. The prepared specimens were gold-sputtered at $10 \mathrm{~mA}$ for 1 minute and observed by SEM.

\section{Results}

Table 1 shows the mean values and standard deviations $(\mathrm{MPa})$ of groups tested in this study. There was no statistical difference between G1, where no treatment was performed and G3, where dentine surface was treated with $\mathrm{NaOCl}$ followed by EDTA. However, between G2, where dentinal surface was treated only with $\mathrm{NaOCl}$, and the other groups, there was statistical difference at a significance level of $1 \%$. An important fact to report is that specimens of $\mathrm{G} 2$ were useless just before the test, since they fractured at a minimum touch, not allowing the microtensile testing. It indicates that $\mathrm{NaOCl}$ had a strong negative influence on the adhesive/dentin bond. The G2's mean value was considered as zero in the statistical analysis.

Table 1. Microtensile bond strength mean values (MPa) and the respective standard deviations.

\begin{tabular}{lccc}
\hline \multicolumn{1}{c}{ Groups } & Mean & Standard deviation & $P$ \\
\hline $\mathrm{G} 1=\mathrm{Coontrol}$ & $8.41^{\circ}$ & \pm 3.51 & \\
$\mathrm{G} 2=\mathrm{NaOCl}$ & $0.00^{\mathrm{b}}$ & \pm 0.00 & $<0.01$ \\
$\mathrm{G} 3=\mathrm{NaOCl}+\mathrm{EDTA}$ & $8.47^{\circ}$ & \pm 3.53 & \\
\hline
\end{tabular}

* Mean followed by the same letters do not show statistical difference

Figure 1 shows by SEM a modified smear layer (1A) that could difficult phosphoric acid etching. It can be observed opened dentine tubules (Fig. 1B) with few pulp tissue remnants and no smear layer. Less resin tags formation are observed in Figure $1 \mathrm{C}$ because of the difficulty of the adhesive system to penetrate throughout the smear layer. In the other hand, effective resin tags formations are seen in Figure 1D.

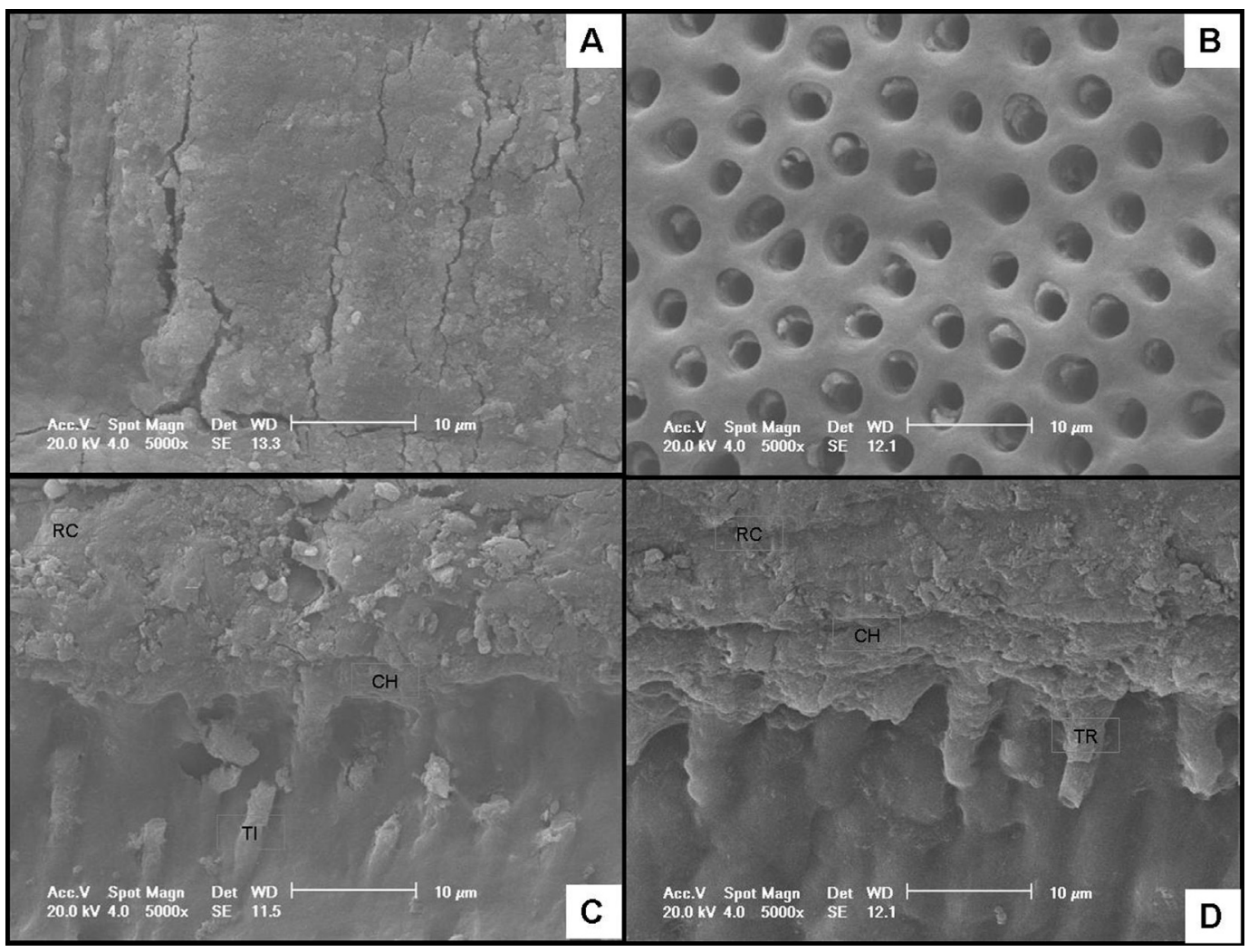

Fig. 1. SEM photomicrographs of dentin after: (A) NaOCl treatment for $1 \mathrm{~h}(5000 \mathrm{x})$; (B) $\mathrm{NaOCl}$ treatment for $1 \mathrm{~h}$ followed by EDTA treatment for $5 \mathrm{~min}(5000 \mathrm{x})$; (C) NaOCl treatment for $1 \mathrm{~h}$ (RC - composite resin, $\mathrm{CH}$ - hybrid layer, $\mathrm{TI}$ - incomplete resin tag (5000x); and (D) $\mathrm{NaOCl}$ treatment for $1 \mathrm{~h}$ followed by EDTA treatment for 5 min (CR - composite resin, $\mathrm{CH}$ - hybrid layer, TR - resin tag (5000x). 


\section{Discussion}

The results showed that G2, treated only with $1 \%$ $\mathrm{NaOCl}$, had its bond strength strongly compromised when compared to the control group G1, and G3 that was treated with EDTA after $\mathrm{NaOCl}$, rejecting the hypothesis under study. This could be caused by organic matrix damage, mainly collagen, after $\mathrm{NaOCl}$ application and could also be attributed to the presence of a $\mathrm{NaOCl}$ modified smear layer after treatment (Figure 1A). This smear layer could difficult phosphoric acid action and monomers infiltration throughout the demineralized dentin because the sodium chlorite already infiltrated in the smear layer could react and partially neutralize the phosphoric acid action (12). Moreover, $\mathrm{NaOCl}$ releases oxygen, and this oxygen could cause a huge inhibition of the adhesive system penetration and polymerization, consequently decreasing the bond strength values (14-16).

The use of EDTA after $\mathrm{NaOCl}$ (G3) in dentinal surface resulted in an increase in bond strength, when compared to the groups that received $\mathrm{NaOCl}$ treatment only (G2) and these results are in accordance to the study of Lay et al. (15). These authors suggest that the EDTA increases bond strength due to its anti-oxidant power via redox reaction, allowing for free radicals polymerization without premature chains or failures. Moreover, it has the ability to remove the smear layer (Fig. 1B) and the residual chlorine ions, what could benefit phosphoric acid etching and enhance resinous monomer penetration through dentinal tubules (17).

Our results are in agreement with the study of Morris et al. (18) and Vongphan et al. (19) who evaluated the chemical effect of irrigating solutions on microtensile bond strength of adhesive system after acid etching (Single Bond) to dentine walls. They noticed that the use of $\mathrm{NaOCl}$ significantly reduced microtensile bond strength. However, the use of $10 \%$ sodium ascorbate significantly increased dentin bond strength after $\mathrm{NaOCl}$ treatment. In this case, the $10 \%$ sodium ascorbate had a similar effect of EDTA in our study.

Nikaido et al. (12) reported that the $\mathrm{NaOCl}$ used during endodontic treatment produces adverse effects on etch-andrinse adhesive systems. Although the use of EDTA had recovered the adhesive resistance to the reference levels, the use of $\mathrm{NaOCl}$ alone had significantly reduced bond strength.

Until recently, endodontically treated teeth were usually treated with a crown, core or dowel (20). However, when they have a sufficient amount of complete coronal structure they can be restored with an adhesive system and resin composite $(21,22)$. It is known that a better bond of restorative materials to dentine walls increases the possibility of marginal sealing, mechanical resistance to mastication stress and durability of restorations (23). The clinical significance of the present study is that the use of EDTA as final irrigating solution during endodontic treatment with $\mathrm{NaOCl}$ is fundamental for tooth restoration without compromising the bond strength when using etch-and-rinse adhesive systems.

However, several aspects of the bond strength of a resin composite in dentin need further research, including the effect of various chemicals used during root canal treatment on canal walls. For example, Moreira et al. (24) observed that $\mathrm{NaOCl}$, whether or not in association with $17 \%$ EDTA, caused alterations to the dentin collagen, whereas chlorhexidine did not. Furthermore, Cecchin et al. (25) showed that the chlorhexidine pretreatment dentin were capable of preserving the bond strength to root dentin for 12 months. Therefore, different protocols of hybridization of root and coronary dentin must be evaluated to increase the bond strength and long-term adhesion of the resin composite.

In conclusion, the application of the $\mathrm{NaOCl}$ irrigating solution significantly decreased the bond strength values. The use of $\mathrm{NaOCl}$ followed by EDTA resulted in bond strength values not statistically different from control group.

\section{References}

1. Pashley DH, Sano H, Ciucchi B, Yoshiyama M, Carvalho R. Adhesion testing of dentin bonding agents: a review. Dent Mater 1995;11:117-25.

2. Meerbeek BV, Munck J, Yoshida SI, Vargas M, Vijay P, Landuyt KV, Lambrechts P, Vanherle G. Buonocore Memorial Lecture. Adhesion to Enamel and Dentin: Current Status and Future Challenges. Oper Dent 2003;28:215-35.

3. Perdigão J, Ramos JC, Lambrechts P. In vitro interfacial relationship between human dentin and one-bottle dental adhesives. Dent Mater 1997;13:218-27.

4. Frankenberger R, Krämer N, Oberschachtsiek H, Petschelt A. Dentin bond strength and marginal adaptation after $\mathrm{NaOCl}$ pre-treatment. Oper Dent 2000;25:40-5.

5. Yamazaki AK, Moura-Netto C, Salgado RJ, Kleine BM, Prokopowitsch I. Ex vivo analysis of root canal cleaning using Endo-PTC associated to $\mathrm{NaOCl}$ and different irrigant solutions. Braz Oral Res 2010;24:15-20

6. Baumgartner JC, Hohal S, Marshall JG. Comparison of the antimicrobial efficacy of $1.3 \%$ $\mathrm{NaOCl} /$ BioPure MTAD to $5.25 \% \mathrm{NaOCl} / 15 \%$ EDTA for root canal irrigation. J Endod 2007;33:48-51.

7. Gomes BPFA, Ferraz CCR, Vianna ME, Berber VB, Teixeira FB, Souza-Filho FJ. In vitro antimicrobial acrivity of several concentrations of sodium hypoclorite and chlorhexidine gluconate in the elimination of Enterococcus faecalis. Int Endod J 2001;34:424-8.

8. Wachlarowicz AJ, Joyce AP, Roberts S, Pashley DH. Effect of endodontic irrigants on the shear bond strength of epiphany sealer to dentin. J Endod 2007;33:152-5. 
9. Çalt S, Serper A. Smear layer removal by EDTA. J Endod 2000;26:459-61.

10. Goldman LM, Goldman M, Kronman JH, Lin PS. The efficacy of several irrigating solutions for endodontics: a scanning electron microscopic study. Oral Surg 1981;52:197-204.

11. Eldeniz AU, Erdemir A, Belli S. Shear bond strength of three resin based sealers to dentin with and without the smear layer. J Endod 2005;31:293-6.

12. Nikaido T, Takano Y, Sasafuchi Y, Burrow MF, Tagami J. Bond strength to endodonticallytreated teeth. Am J Dent 1999;12:177-80.

13. Farina AP, Cecchin D, Barbizam JV, Carlini-Júnior B. Influence of endodontic irrigants on bond strength of a self-etching adhesive. Aust Endod J 201 1;37:26-30

14. Ruegeberg FA, Margeson DH. The effect of oxygen inhibition on an unfilled/filled system. J Dent Res 1990;69:1652-8.

15. Lai SCN, Mak YF, Cheung GSP, Osorio R, Toledano M, Carvalho RM, et al. Reversal of compromised bonding to oxidized etched dentine. J Dent Res 2001 ;80:1919-24.

16. Nascimento JS, Carrilho MR, Goes MF, Zaia AA, Gomes BPFA, Souza-Filho FJ, Ferraz CCR. Effect of Chemical Irrigants on the Bond Strength of a Self-Etching Adhesive to Pulp Chamber Dentin. J Endod 2006;32:1088-90.

17. Miyasak K, Nakabayashi N. Combination of EDTA conditioner and Phenyl-HEMA selfetching primer for bonding to dentin. Dent Mater 1999;15:153-7.

18. Morris MD, Lee KW, Agee KA, Bouillaquet S, Pashley DH. Effects of resin cement to endodontic surfaces. J Endod 2001;27:753-7.

19. Vongphan N, Senawongse P, Somsiri W, Harnirattisai C. Effects of sodium ascorbato on microtensile bond strength of total-etching adhesive system to $\mathrm{NaOCl}$ treated dentine. Dent 2005;33:689-95.

20. Boone KJ, Murchison DF, Schindler WG, Walker WA. Post retention: the effect of post-space preparation, cementation time, and different sealers. J Endod 2001;27:768-71.

21. Hernandez R, Bader S, Boston D, Trope M. Resistance to fracture of endodontically treated premolars restored with new generation dentine bonding systems. Int Endod J 1994;27:281-4.

22. Saupe WA, Gluskin AH, Radke RA Jr. A comparative study of fracture resistance between morphologic dowel and cores and a resin-reinforced dowel system in the intraradicular restoration of structurally compromised. Quintessence Int 1996;27:483-91.

23. Fortin D, Swift EJ, Denehy GR, Reinhardt JW. Bond strength and microleakage of current dentin adhesives. Dent Mater 1994;10:253-8.

24. Moreira DM, Almeida JF, Ferraz CC, Gomes BP, Line SR, Zaia AA. Structural analysis of bovine root dentin after use of different endodontics auxiliary chemical substances. Endod 2009;35:1023-7.

25. Cecchin D, Almeida JF, BPFA Gomes, Zaia AA, Ferraz CC. Effect of Chlorhexidine and Ethanol on the Durability of the Adhesion of the Fiber Post Relined with Resin. J Endod $2011 ; 37: 678-83$ 